\title{
Riparian Buffer Strips as a Multifunctional Management Tool in Agricultural Landscapes: Introduction
}

\author{
Marc I. Stutter, Wim J. Chardon, and Brian Kronvang
}

Catchment riparian areas are considered key zones to target mitigation measures aimed at interrupting the movement of diffuse substances from agricultural land to surface waters. Hence, unfertilized buffer strips have become a widely studied and implemented "edge of field" mitigation measure assumed to provide an effective physical barrier against nitrogen $(\mathrm{N})$, phosphorus $(\mathrm{P})$, and sediment transfer. To ease the legislative process, these buffers are often narrow mandatory strips along streams and rivers, across different riparian soil water conditions, between bordering land uses of differing pollution burdens, and without prescribed buffer management. It would be easy to criticize such regulation for not providing the opportunity for riparian ecosystems to maximize their provision for a wider range of ecosystem goods and services. The scientific basis for judging the best course of action in designing and placing buffers to enhance their multifunctionality has slowly increased over the last five years. This collection of papers aims to add to this body of knowledge by giving examples of studies related to riparian buffer management and assessment throughout Europe. This introductory paper summarizes discussion sessions and 13 selected papers from a workshop held in Ballater, UK, highlighting research on riparian buffers brought together under the EU COST Action 869 knowledge exchange program. The themes addressed are (i) evidence of catchment- to national-scale effectiveness, (ii) ecological functioning linking terrestrial and aquatic habitats, (iii) modeling tools for assessment of effectiveness and costs, and (iv) process understanding enabling management and manipulation to enhance pollutant retention in buffers. The combined understanding led us to consider four principle key questions to challenge buffer strip research and policy.

Copyright $\odot 2012$ by the American Society of Agronomy, Crop Science Society of America, and Soil Science Society of America. All rights reserved. No part of this periodical may be reproduced or transmitted in any form or by any means, electronic or mechanical, including photocopying, recording, or any information storage and retrieval system, without permission in writing from the publisher.

J. Environ. Qual. 41:297-303 (2012)

doi:10.2134/jeq2011.0439

Posted online 3 Feb. 2012

Freely available online through the author-supported open-access option.

Received 22 Nov. 2011.

*Corresponding author (marc.stutter@hutton.ac.uk).

(c) ASA, CSSA, SSSA

5585 Guilford Rd., Madison, WI 53711 USA
S OME FORM OF BUFFER STRIP has long been a feature of agricultural landscapes. Their occurrence may have arisen as a side effect of rough or wet land difficult to work or an intentional setting aside areas resulting from environmental legislation or compensation schemes. It is well documented how riparian buffers perform many key functions, such as the ability to trap nutrients, sediment, or pesticides transported from upslope areas. This evidence has contributed to a number of different forms of buffer strips being applied according to the localized landform, slope, and field use (Fig. 1). This can vary from a zone with the same crop as the adjacent field, but not receiving fertilizers, to an (unfertilized) zone with a different vegetation and a wet zone aimed at stimulating denitrification. In addition to their primary role of trapping nutrients and sediment, riparian buffers can provide multiple benefits in terms of biodiversity and water regulation.

Despite the decades of research concerning buffer strips, the scientific literature remains primarily biased toward consideration of single issues. Examples of this are in the technical reviews of functions such as sediment trapping (Liu et al., 2008; Gumiere et al., 2011) or pesticide retention (Arora et al., 2010). However, modern scientific thinking conceptualizes components of landscapes in terms of the provision of a range of interacting ecosystem goods and services (Costanza et al., 1997). According to this approach, we should revise our methodologies of designing, understanding, and evaluating riparian buffer strips to maximize these possible benefits, and this should be according to local needs, pressures, and landscape setting. Figure 2 shows important components of this process. It is necessary to consider the vulnerability of a number of areas of catchments to prioritize resources into effective buffer placement. This may involve evaluating zones of more vulnerable ecological function, as well as the most intensive agricultural areas. There needs to be a process of stakeholder involvement to incorporate local knowledge and decision making. This should be done alongside consideration of technical knowledge, potentially involving modeling. Finally, a set of tools, using dialog, monitoring, and modeling, is required to evaluate the cost-effectiveness of the decisions made and resources used for riparian management.

Among the many papers considering specific buffer functions in isolation, a progression of thinking has occurred toward

M.I. Stutter, The James Hutton Institute, Aberdeen. AB15 8QH, UK; W.J. Chardon, Alterra, Wageningen, The Netherlands; B. Kronvang, Dep. of Bioscience, Aarhus Univ., Silkeborg, Denmark. Assigned to Associate Editor Rory Maguire.

Abbreviations: BSE, buffer strip effectiveness; GHG, greenhouse gas; RBMP, River Basin Management Plan; WFD, Water Framework Directive. 


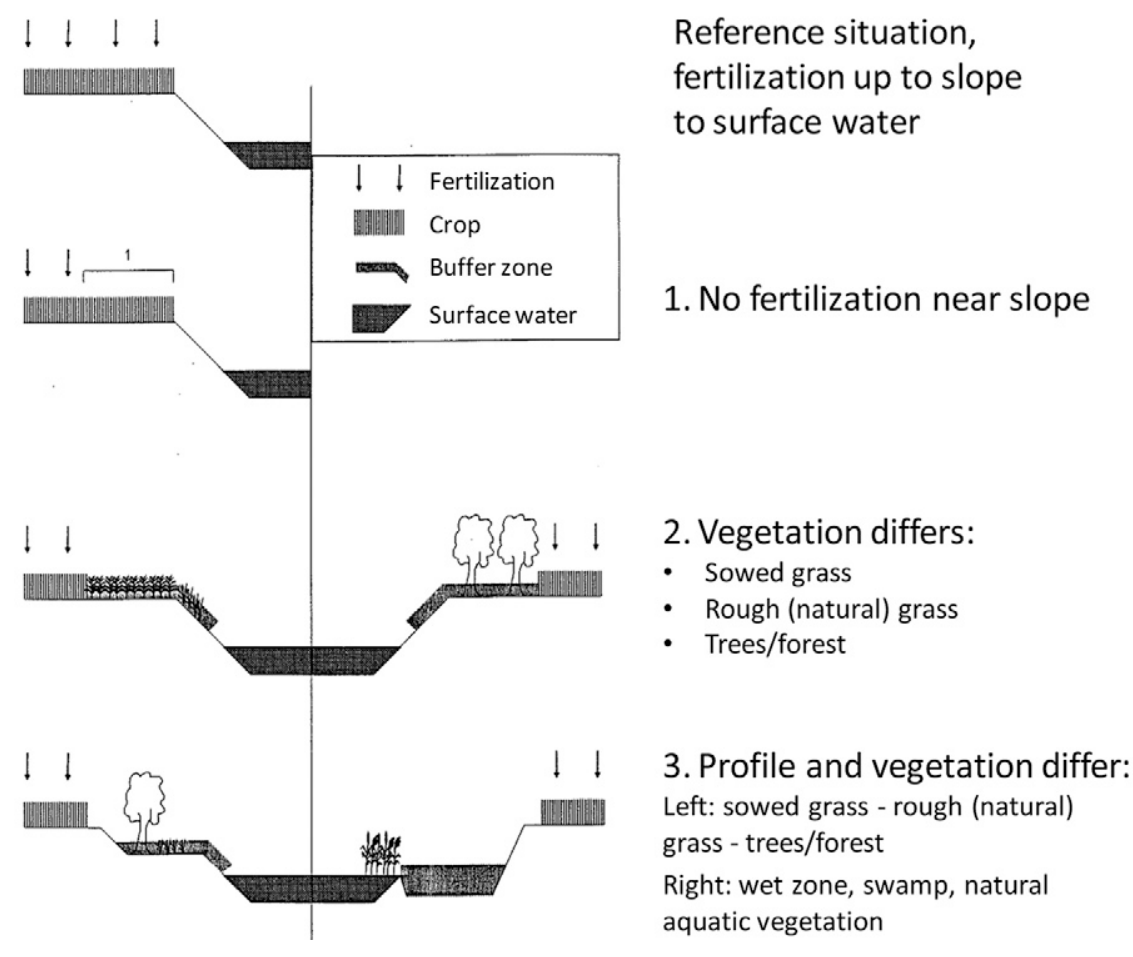

Fig. 1. Examples of different types of buffer zones. Top: reference situation, fertilizer is applied up to the slope of surface water. 1: No fertilizer is applied near the slope, crop is unchanged. 2: Crop is replaced by a (semi-)natural vegetation in the buffer zone. 3: Both profile and vegetation differ from rest of field. (after Arts et al., 1998).

multiple functions and ecosystem interactions. Dorioz et al. (2006) considered retention of the single pollutant P, but from the viewpoint of cycling across the whole microbial soil-plant system. Vidon (2010) tackled the function of diffuse pollution mitigation but considered the multiple challenges associated with simultaneously controlling a range of contaminants. In another paper, Vidon et al. (2010) went on to evaluate spatiotemporal aspects of nutrient retention, using a concept that buffer strips needed to control "hot spots and hot moments." Other papers have begun to consider a number of diverse functions of buffers. Borin et al. (2010) reviewed several Italian studies considering nutrient and herbicide retention, food fuel production, aesthetic value, and $\mathrm{CO}_{2}$ capture potential. Mander et al. (2005) pre- sented an editorial summary of a collection of papers from two international meetingsthe International Workshop on Efficiency of Purification Processes in Riparian Buffer Zones: Their Design and Planning in Agricultural watersheds (Hokkaido, Japan, 2001) and the International Conference on Ecological Engineering for Landscape Services and Products (Christchurch, New Zealand, 2001). This summary gives an overview of research into the combination of nutrient retention and ecological functioning.

The current collection of papers is an outcome of a five-year knowledge exchange program funded by the EU under the COST Action 869, "Mitigation options for nutrient reduction in surface water and groundwaters." This scientific network has focused on the implementation and assessment of water quality measures adopted into EU nations River Basin Management Plan (RBMP) programs in fulfilling their obligations to maintain and improve Good Ecological Status under the EU Water Framework Directive (2000/60/EEC) (WFD). A workshop held in Ballater, UK (April 2010) brought together 45 scientists, catchment practitioners, and regulators from $15 \mathrm{EU}$ countries to focus on how riparian buffer strips can be better implemented, managed, and modeled to maximize their multiple benefits in landscapes. There is a need to set appropriate goals for functional restoration of riparian areas without excessively affecting the farming businesses, to provide tools for assessment, and evidence for achieving desired goals. The underlying principal was that an investment of assigning valuable space for riparian features beyond the statutory minimal guidelines for buffer widths could be justified by the multiple functions attained. We suggest that promoting riparian buffers on the basis of interrupting transport of N, P, and sediments is an important function of which evidence should be assessed to account for immediate

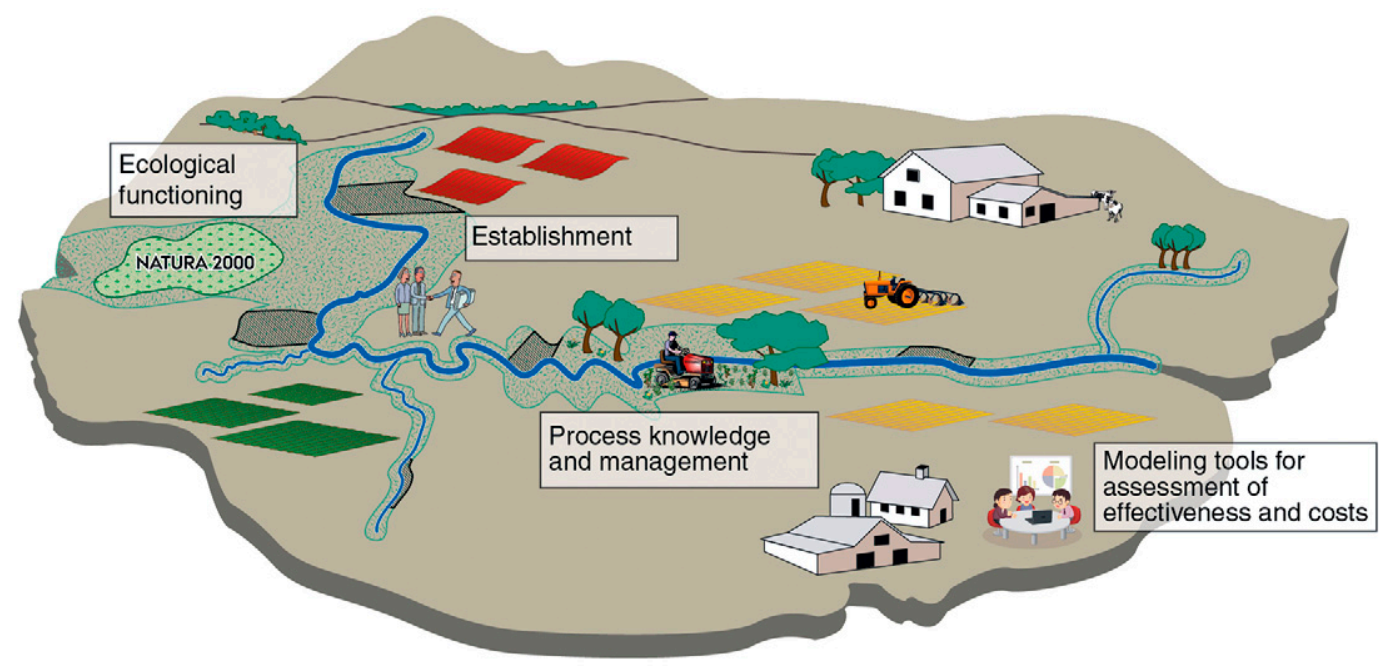

Fig. 2. A schematic diagram showing how buffer strips may be established in a catchment together with local stakeholders to utilize their multifunctionality in an optimal way. 
WFD goals. However, we need to recognize ways to improve nutrient retention functions and conflicts and interactions between diffuse pollution functions and other services (Table 1) as new policies emerge governing a range of ecosystem services. Analysis of the buffer strip scientific literature (Table 1) suggests that research into many of these multiple functions is not well developed. Evidence for multiple functionality is therefore needed to inform and persuade regulators and land managers to implement more effective riparian buffers and devote greater resources toward this goal.

This introductory paper aims to set the context for this special collection of papers from the Ballater workshop that, when taken together, further explore the range of multiple benefits, or negative side-effects, associated with riparian buffers in European landscapes. We conclude by discussing the issues raised by these interacting functions in terms of design, placement, and ongoing management for maximizing benefits and how we evaluate and promote these benefits. Thirteen papers comprise this special collection, grouped into the four themes presented below.

\section{Evidence of Catchment- to National-Scale Effectiveness}

An extensive body of literature exists documenting buffer trapping efficiencies with respect to sediments and phosphorus, yet these observations mainly arise from plot-scale field studies over single to limited cycles of rainfall events. Therefore, processes of gradual erosion of material through buffers, formation of convergent flow paths, soil nutrient saturation, and effects of landscape heterogeneity are poorly encompassed. This highlights the need for long-term observations (i.e., years and longer) of buffer impacts at catchment scales.

Kronvang et al. (2012) document the role of bank erosion to sediment and P delivery across a large catchment in Denmark, in relation to factors of buffer width and vegetation, stream size, and channelization. Bank erosion was a large contribution to P delivery (21-62\% of diffuse sources) and strongly inversely related to the presence of natural trees, which stabilized the banks. This showed a clear benefit for forested riparian buffers at catchment scales, not for interrupting transport of nutrients from the fields but rather in limiting the riparian soils themselves as sources. However, Bergfur et al. (2012) call for caution in the ability of catchment studies to link buffering to nutrient and ecological improvements using a "regulatory-style" data collection program. Bergfur et al. (2012) present a decade of monitoring the improvements in chemical and macroinvertebrate quality across a $50-\mathrm{km}^{2}$ mixed-agriculture headwater in Scotland. Despite widespread buffering on several monitored subcatchments, they found no significant improvements relative to control reaches in chemistry or ecology attributable to buffering. A septic tank replacement masked the subtle effects of buffering in terms of $\mathrm{P}$ concentrations. It could not be inferred if the lack of positive results was due to ineffectiveness of buffering, inadequate sampling strategy, or inherent system

Table 1. Primary buffer strip functions, associated issues, and summaries of the level of knowledge, guidance policy, and funding (for the three EU countries of the authors) and the analysis of these functions across a survey of published buffer strip papers from ISI journals over the last five years.

\begin{tabular}{|c|c|c|c|c|}
\hline Function & Issues & $\begin{array}{c}\text { State of } \\
\text { knowledget }\end{array}$ & $\begin{array}{l}\text { Guidance, policy, } \\
\text { and fundingt }\end{array}$ & $\begin{array}{l}\text { References \% } \\
\text { inclusion } \neq\end{array}$ \\
\hline \multirow{4}{*}{$\begin{array}{l}\text { Controlling diffuse } \\
\text { pollution transport }\end{array}$} & $\underline{\text { Nutrients }}$ & ++ UK§ & ++ UK & $56 \%$ \\
\hline & $\begin{array}{l}\text { Site specific soil and flowpath factors make placement and } \\
\text { prediction of effects difficult. Insufficient knowledge of } \\
\text { catchment scale effectiveness, long term P storage, GHG trade- } \\
\text { offs. Works best when linked to in-field source control measures. }\end{array}$ & $\begin{array}{r}++\mathrm{DK} \\
+\mathrm{NL}\end{array}$ & $\begin{array}{r}++\mathrm{DK} \\
-\mathrm{NL}\end{array}$ & \\
\hline & Pathogens and pesticides & - UK & - UK & \\
\hline & Issues of residence time and transformations in soils & $\begin{array}{l}-\mathrm{DK} \\
-\mathrm{NL}\end{array}$ & $\begin{array}{l}-\mathrm{DK} \\
-\mathrm{NL}\end{array}$ & \\
\hline $\begin{array}{l}\text { Habitat improvement } \\
\text { and ecological } \\
\text { connectivity }\end{array}$ & $\begin{array}{l}\text { Conflict with nutrient retention, best as part of combined in-field and } \\
\text { edge of field conservation measures. May require outer buffer to } \\
\text { protect inner riparian eco-zone. Requires tools for better landscape } \\
\text { planning. Potentially ecological quality and the most intensive food } \\
\text { production cannot be reconciled within the same landscapes. }\end{array}$ & $\begin{array}{r}++\mathrm{UK} \\
-\mathrm{DK} \\
+\mathrm{NL}\end{array}$ & $\begin{array}{r}++ \text { UK } \\
- \text { DK } \\
-\mathrm{NL}\end{array}$ & $36 \%$ \\
\hline Stream shading & $\begin{array}{l}\text { Should be broad leaved trees. Protects watercourse from } \\
\text { temperature extremes. Increases woody debris and C inputs. }\end{array}$ & $\begin{array}{l}+\mathrm{UK} \\
+\mathrm{DK} \\
+\mathrm{NL}\end{array}$ & $\begin{array}{l}-\mathrm{UK} \\
+\mathrm{DK} \\
-\mathrm{NL}\end{array}$ & $5 \%$ \\
\hline $\begin{array}{l}\text { Hydrological } \\
\text { connectivity }\end{array}$ & $\begin{array}{l}\text { Useful reconnection of waters with their flood plains, conflicts } \\
\text { with soil drained for farming. Wetlands are effective bioreactors } \\
\text { for N. Stores flood peak flow. Contaminated sediments may } \\
\text { pollute the floodplain. }\end{array}$ & $\begin{array}{r}+\mathrm{UK} \\
++\mathrm{DK} \\
-\mathrm{NL}\end{array}$ & $\begin{array}{r}-\mathrm{UK} \\
++\mathrm{DK} \\
-\mathrm{NL}\end{array}$ & $14 \%$ \\
\hline Carbon sequestration & $\begin{array}{l}\text { Potential to sequester } \mathrm{C} \text { in buffer soils and via tree planting. } \\
\text { Potential interaction with DOC leaching and turnover of } \mathrm{N} \text { and } \mathrm{P} \text {, } \\
\text { or with GHG emissions. }\end{array}$ & $\begin{array}{l}-\mathrm{UK} \\
-\mathrm{DK} \\
-\mathrm{NL}\end{array}$ & $\begin{array}{l}-\mathrm{UK} \\
-\mathrm{DK} \\
-\mathrm{NL}\end{array}$ & $12 \%$ \\
\hline Biomass production & $\begin{array}{l}\text { May economically offset land taken from food crops (using } \\
\text { timber or biofuel production). Needs to be harvested without } \\
\text { degradation of riparian zone. }\end{array}$ & $\begin{array}{l}-\mathrm{UK} \\
-\mathrm{DK} \\
-\mathrm{NL}\end{array}$ & $\begin{array}{l}-\mathrm{UK} \\
-\mathrm{DK} \\
-\mathrm{NL}\end{array}$ & $8 \%$ \\
\hline Cultural services & $\begin{array}{l}\text { Could encourage habitat for hunting species (fishing, deer, game } \\
\text { birds). Use for public access, recreation and education. May } \\
\text { harbor crop pests such as rabbits. }\end{array}$ & $\begin{array}{l}+\mathrm{UK} \\
-\mathrm{DK} \\
-\mathrm{NL}\end{array}$ & $\begin{array}{l}-\mathrm{UK} \\
-\mathrm{DK} \\
-\mathrm{NL}\end{array}$ & $6 \%$ \\
\hline
\end{tabular}

†These are the authors'judgments of the state of knowledge and practical guidance and incentives for implementation and uptake of buffers among all stakeholder groups in their prospective countries. The notation system is: $-\ldots$, minimal; - , limited; +, good; ++ , very good.

¥A selection of 100 scientific papers was taken from the Web of Science search tool, searching on criteria "Riparian buffer strip" between 1997 and 2011. § UK, United Kingdom; DK, Denmark; NL, the Netherlands. 
lags in recovery. These are important messages for future monitoring of effectiveness in terms of maintaining consistent longterm records at appropriate spatiotemporal resolutions.

Another cautionary note is if we expect buffers to act as "end of pipe solutions" to the terrestrial environment's outputs at the expense of appropriate source controls. A good example is relying on denitrification in buffers to allow high rates of $\mathrm{N}$ fertilizer application to continue. In this case, a functioning buffer could have greenhouse gas (GHG) implications, and a poorly functioning buffer would have an aquatic eutrophication effect. Noij et al. (2012) present a detailed experimental assessment of buffer strip effectiveness (BSE) in terms of $\mathrm{N}$ concentration reductions across 5-m grass buffers for a range of soil and hydrogeological conditions found across the Netherlands. Low and nonsignificant BSE (a maximum of 10\%) were explained by unfavorable hydrological conditions for denitrification (associated with deeper groundwater flowpaths, low residence times in buffers, and surface runoff). Hence, the inclusion of a basic unfertilized grass strip as a border for intensive crop production was an ineffective policy tool for reducing $\mathrm{N}$ losses to surface waters at a national scale. In the accompanying paper by Heinen et al. (2012), the degree to which landscape and soil factors control the $\mathrm{P}$ retention efficiency of 5-m buffer strips is evaluated. They found no significant effects of $5-\mathrm{m}$ buffer strips compared with reference treatment for P retention in this landscape with deeply permeable soils.

\section{Ecological Functioning Linking Terrestrial and Aquatic Habitats}

The riparian area is a critical zone where the habitat qualities of the land and stream ecosystems are closely linked. It must be recognized, however, that there are interactions between the elevated nutrient status often occurring in buffer soils and their ability to support certain desired vegetation communities. Dybkjær et al. (2012) examine the diversity in riparian plant communities in relation to stream order across Denmark. Community type numbers increased with stream size, but perceived "high-value" protected communities decreased with increasing stream size and eutrophication pressures. The authors conclude that wide buffers are required to protect sensitive, high-value habitats from agricultural impacts. However, there is great pressure against legislating for wider buffers in many farming landscapes in Europe, without costly (and often rare and competitive) compensatory schemes. Hence, narrow buffers are more common in many EU countries. McCracken et al. (2012) present a study on the biodiversity benefits, in terms of vegetation composition and invertebrates as food for farmland birds, of established, narrow, fenced riparian buffers in Scotland, which they studied over four years. Such buffers had unmanaged dense vegetation showing limited benefits in invertebrate diversity and poor habitat for birds to forage. The authors suggest a management regime to maximize biodiversity should allow grazing animals to be permitted within the buffer at selected times to crop the vegetation. However, the fencing out of livestock from the buffer is perceived to be the key benefit in limiting $\mathrm{P}$ and pathogen transport to the watercourse. Hence, a conflict is highlighted between management for biodiversity compared with best practice for diffuse pollution control. Stockan et al. (2012) compared vegetation characteristics between riparian buffer classes of degraded, buffered, and target natural riparian habitats. They observed a strong control of the interrelationship between tree canopy cover, soil nutrients, and stream morphology on riparian vegetation, with the incorporation of trees a beneficial component of buffers. Without trees, buffers even when established for a decade could not achieve a stable habitat.

McCracken et al. (2012) also raise the important issue that buffers should not be seen as operating independently from the surrounding land, in ecological as well as diffuse pollution terms. Buffers promote good habitat when field and upstream conditions also have good complementary aspects of function. This connectivity of ecological function is also addressed by Weigelhofer et al. (2012), who studied the interactions between the riparian terrestrial environment and in-stream nutrient retention. Weigelhofer et al. (2012) explored in-stream retention of $\mathrm{PO}_{4}$ and $\mathrm{NH}_{4}$ in Austrian stream reaches with forested riparian buffers relative to control reaches. Within forested riparian areas, woody debris and the associated formation of linked pools of low water velocity along stream sections enhanced transient storage and mediated greater $\mathrm{N}$ uptake by autotrophs. Uptake of P was not consistent with hydrological factors, and eutrophied streams may already be P saturated. Hence, biodiversity and functioning of microbial communities in-stream can control the resilience to future nutrient inputs unless, as found by Weigelhofer et al. (2012), system thresholds for nutrient saturation have already been attained.

\section{Modeling Tools for Assessment of Effectiveness and Costs}

Modeling of buffer functions is crucial to evaluating effectiveness across different environments, but the influential finescale landscape features are difficult to take into account and upscale. Even in relatively data-rich "research catchments," we are failing to characterize all the environmental interactions required to understand and model buffer systems. Heinen et al. (2012) present a field experimental and mathematical modeling framework for investigating BSE in deep, permeable sandy soils (as a partner paper for the results shown in Noij et al., 2012). The risks of only establishing the chemical changes in shallow groundwaters are presented, when actually the deep groundwater flowpaths account for the observations of limited BSE. The authors give future recommendations for such experiments and show how the results were made robust by the inclusion of reference treatments. This paper shows an important combination of hydrochemical and hydrological tracing and modeling tools for evaluating results and uncertainties.

Our biophysical effectiveness assessment of buffers should be linked to include integrative modeling of biophysical, ecological, and social aspects. Balana et al. (2012) present a framework for balancing the effectiveness of placement of buffer zones of three widths (from baseline regulatory $2 \mathrm{~m}$ to $20 \mathrm{~m}$ ) against different land-use risk classes for P exports against the economic gross margin losses. The authors present this method in the context of a $13-\mathrm{km}^{2}$ catchment in Scotland failing to meet standing water $P$ targets under the WFD. The framework provides a method to optimize on a field-by-field basis using GIS data inputs, agricultural census data, P export coefficients, 
buffer width versus efficiency data, and documented farm economic returns. Such an approach highlights two important messages in aiming to achieve a real WFD goal for surface water P reduction. One concerns landscape design, namely, that most cost-effective buffering was achieved by optimizing buffering against higher risk crops while limiting economic losses. Another message is that the required $\mathrm{P}$ load reduction could only be met by widespread use of $20-\mathrm{m}$ buffers, which were unrealistic in this farming environment. Currently, in the UK (and other areas), a uniform riparian buffer strip width is required by agri-environment regulations. It is easier for countries to advise a national set of buffer guidelines with a uniform buffer strip width than to provide the resources to judge specific problem areas and advise appropriate specific action such as a varying width.

\section{Process Knowledge Contributing to Management and Manipulation to Enhance Pollutant Retention in Buffers}

There remains a need for knowledge of riparian buffer soil nutrient cycling processes. Many of these processes and their study methods are transferable from the literature on wetlands, but there is also a need to look into mechanisms for betterdrained edge-of-field and wooded buffers as typically found in European farming landscapes. This fundamental knowledge is highly pertinent for buffer soils to be managed to provide a wider range of ecosystem services such as degradation of pesticides, sequestration of soil C, or support of high biodiversityvalue plant communities. The retention of $\mathrm{P}$ in buffer soils is a good example. While $\mathrm{N}$ may be lost to the atmosphere, the lack of such a removal process for $\mathrm{P}$ from soils means that $\mathrm{P}$ saturation is likely to lead to a finite buffer lifespan and eventual $\mathrm{P}$ losses to waters. Roberts et al. (2012) reviewed plot-scale studies, showing that riparian buffers can enhance dissolved P delivery to surface waters. The mechanisms are collated into a conceptual model of factors influencing $\mathrm{P}$ retention. Mobilization of $\mathrm{P}$ by biological solubilization processes are more dominant in vegetated buffer strip soils than in adjacent fields and can lead to delivery of a more bioavailable form of $P$. The specific relationships between soil physicochemical, microbiological properties, and nutrient release in buffer soils are explored by Stutter and Richards (2012). These authors used a combined assay for release of dissolved $\mathrm{P}, \mathrm{N}$, and $\mathrm{C}$ and particulate $\mathrm{P}$ to look for evidence of enhanced nutrient release from buffer soils relative to adjacent field soils across 19 sites in Scotland. The authors conclude that increased biogeochemical cycling rates (strongly mediated by soil microbiological communities) led to increasing $\mathrm{C}, \mathrm{N}$, and $\mathrm{P}$ solubility and it was recommended these should be the focus of soil manipulations to increase buffer soil nutrient retention. This work confirms the conclusions of an earlier study (Stutter et al., 2009) undertaken at a single location and shows the importance of management to enhance biogeochemical aspects of buffer nutrient retention.

This brings up the question of whether and how we can manage buffer strips to slow or stop nutrient saturation so that buffers continue to provide an effective barrier against the transfer of nutrients to the watercourse. Vegetation uptake may not be sufficient to remove nutrients, although several EU countries prescribe vegetation cutting and removal to limit $\mathrm{P}$ buildup. Another answer is to view buffers as a final stage in a "treatment train" approach. Such a combined strategy must limit nutrients at their sources and interrupt transport on the hillslope to limit the material flows into buffers. However, these approaches may conflict with the ecosystem service of food production in highly intensive production landscapes. Such locations may necessitate technological solutions. Two examples are presented of the use of soil amendments to improve water quality in Nordic countries. Kirkkala et al. (2012) analyze long-term (2- to 6-yr trials) water quality data for the performance of sand-lime filters placed in riparian areas of a lake catchment experiencing eutrophication problems due to P. Trials of three filters showed reduced sediment and total $\mathrm{P}$ export, while dissolved $\mathrm{P}$ performance depleted over time. In terms of reducing $\mathrm{N}$ transfer across the filters, the effects were limited and variable between sites, but $\mathrm{N}$ was not the target of this technology. The authors note that the high $\mathrm{pH}$ of runoff may need to be neutralized before entering streams and that the fate of sorbed P needs to be established in the long term. Another example is presented by Uusi-Kämppä et al. (2012), who evaluate a range of $\mathrm{P}$ binding $\mathrm{Fe}$ or $\mathrm{Ca}$ compounds applied to 40 intact soil microcosms of buffer zone grassland soils. The authors aimed to explore methods of reducing soluble P runoff from soils under freeze-thaw cycles in Finland. Under laboratory simulations, soluble reactive $\mathrm{P}$ was reduced by 57 to $80 \%$ in surface runoff from soils manipulated with Fe-gypsum and ferric sulfate granules but was not affected by additions of ordinary gypsum or chalk. The amendment of buffer soils with Fe compounds to increase $\mathrm{P}$ retention should be investigated now at field scales. These papers are good examples of manipulative managements for future use in highly productive landscapes. However, soil amendment materials must be cheap, readily available materials of low hazard if they are to gain acceptance. The concept of nutrient capture systems will be most attractive where recycling of the nutrients to the fields is shown to be possible and cost-effective. Such innovation is necessary to tighten the $\mathrm{P}$ efficiency of farming in light of issues of $\mathrm{P}$ fertilizer resource security.

\section{Future Needs in Research and Guidance for Riparian Buffers}

The issues addressed by the collection of papers in this special section led to a set of questions intended to act as challenges for the research, regulatory, and practitioner communities.

\section{How can we bring efficient placement and design of buffers in landscapes to minimize diffuse pollution delivery?}

Phosphorus saturation (Stutter and Richards, 2012; Roberts et al., 2012) provides an example of why buffers must not be considered an ultimate edge of field solution without tackling the rates of inputs of $\mathrm{P}$ into the buffer using linked source controls (Vidon et al., 2010). Technological solutions to introduce P binding compounds into soils (Uusi-Kämppä et al., 2012; Kirkkala et al., 2012) may be utilized, but they may 
not be readily adopted by the farming community. Balana et al. (2012) showed that linked socioeconomic-biophysical modeling can provide an initial screening of positioning and design of buffers at a landscape scale. In a recent Danish evaluation of buffers (Kronvang et al., 2010, 2011), it was concluded that the mandatory $10-\mathrm{m}$-wide riparian buffers would have been more cost-effective if buffers were targeted to critical areas. However, targeting buffer strips of variable widths according to the risk of pollution to watercourses requires a regulatory approach that is flexible and that can provide for the inherent costs in guidance, assessment of compliance, and administration of compensation payments.

\section{What are the key aspects and aims in the ongoing management of riparian buffers?}

A better understanding of the management actions, and key locations for management, is necessary to ensure that buffer strips continue to provide a range of multiple benefits. Management must either be simple, be made mandatory, or yield products or obvious benefits to become accepted by practitioners. An example is in the annual cutting and removal of vegetation to introduce a sink and removal mechanism for $\mathrm{P}$, which then provides a green manure for application back onto the fields. Use of a tractor and offset mower operated from upslope of the buffer may be possible. However, many European buffer strips are fenced and too narrow to drive within the fence. The use of animals to graze the grass would meet with resistance due to the strong benefits for bank erosion and pathogen control associated with fencing animals out of the buffer. Studies are required to bring guidance for management that is practical, utilizes local practitioner knowledge, and accounts for weather, soil conditions, and landscape.

\section{How can we maximize benefits for riparian habitat restoration through buffer design?}

Despite considerable research on natural riparian zones, the special situation of buffer strip ecology is less understood. Buffers are often restored from, or in direct proximity to, intensively managed land. Due to high levels of retained nutrients (Stutter and Richards, 2012), buffer strips seem unable to develop perceived high-status plant communities (Dybkjær et al., 2012). Riparian trees should be promoted as part of a sustainable buffer habitat to sequester nutrients, provide shade to the stream, outcompete less-desirable plants, and provide habitat. Economic returns from timber production should be promoted as an incentive to widening buffer strips beyond widths subsidized by agri-environmental schemes. There may be a need for a two-stage buffer zone to allow multiple benefits for diffuse pollution mitigation and ecological services in intensely farmed areas. This would comprise an upslope grass zone for trapping sediments and contaminants and then a protected "ecological" zone adjacent to the stream where trees are used for habitat and bank stabilization purposes (Schultz et al., 1997). Otherwise, society may have to face difficult questions concerning whether there is a need for regional separation of true biodiversity areas from intensive food production areas. In Denmark, national mapping of Natura 2000 habitats (an EU nature conservation program) is being linked to buffer place- ment to assist in linking protected habitats with widened buffers along river corridors.

\section{What are the most important aspects of multiple benefits to different stakeholders, and how should we go about observing progress to achieving desired goals?}

Many stakeholders' opinions must be included in deciding which of a range of multiple benefits to prioritize. Scientific approaches may anticipate a set of idealized objectives to be met. Dybkjær et al. (2012) provide an example for which the perceived targets for successful restoration of riparian vegetation are certain high conservation-value plant communities, yet these cannot be attained due to elevated soil nutrient levels. Does this mean ecological success is not attained, or that the metrics are not appropriate to that situation? A modeling approach such as multiple criteria analysis can combine and assess multiple benefits (Koo and O'Connell, 2006), and a typical ranked scoring system based on expert judgment may be the correct pragmatic solution. However, combining diverse multiple benefits such as increasing the biodiversity of farmland birds (McCracken et al., 2012) alongside nutrient sequestration using soil amendments (Uusi-Kämppä et al., 2012) remains challenging. This would call for a revised modeling strategy, such as the framework for grassland ecosystem services discussed by MacLeod and Ferrier (2011), incorporating factors of scale, connectivity, thresholds, and indicators.

\section{Does the existing policy framework support the achievement of multiple benefits?}

Many of the policies that directly affect buffer strips have complex interactions, such as between food production, diffuse pollution mitigation, climate change and biofuel production, natural flood management, GHG and soil carbon, and biodiversity. Yet these policies are often conceived of and applied independently. Current systems of legislation and rural development payments are biased toward single issues. How do we move to a system of valuing and accounting for the multiple functions of beneficial landscape features such as riparian buffers? There are limited examples of attempts to document dual goals for a wide number of mitigation measures (e.g., combining diffuse pollution mitigation and GHG balances) that are useful for policy formation and guidance. The reform of the European Union's agricultural policy post-2013 states that "farmers must devote $7 \%$ of their eligible area excluding permanent grassland (thus mainly a requirement on the arable area including permanent crops) to ecological focus including land left fallow, buffer strips and afforested areas" (Matthews, 2011 , p. 7). If rural landscapes are to see a substantial societal investment in set-aside areas such as buffer strips, we need to plan to make these areas most productive in terms of the ecosystem benefits they bring.

\section{Acknowledgments}

This work was supported by the European Union's COST Action 869. Marc Stutter was also supported by the Scottish Government's Rural and Environmental Science Analytical Services Division. Brian Kronvang was supported by the Danish Strategic Research Council Project- MONITECH (Grant No. 2104-08-0050). Wim Chardon 
was also supported by the Dutch Agricultural Governments research program concerning the WFD in relation to Nutrients and Manure (project BO-12.07-009-001).

\section{References}

Arts, G.H.P., M. Fellinger, and P.F.M. Verdonschot. 1998. Ecological research on the effects of buffer zones along water courses: A literature research on functioning, effectiveness, and opportunities of buffer zones. (In Dutch.) Report STOWA, Utrecht, the Netherlands.

Arora, K., S.K. Mickelson, M.J. Helmers, and J.L. Baker. 2010. Review of pesticide retention processes occurring in buffer strips receiving agricultural runoff. J. Am. Water Resour. Assoc. 46:618-647.

Balana, B.B., M. Lago, N. Baggaley, M. Castellazzi, J. Sample, M. Stutter, B. Slee, and A. Vinten. 2012. Integrating economic and biophysical data in assessing cost-effectiveness of buffer strip placement. J. Environ. Qual. 41:380-388 (this issue). doi:10.2134/jeq2010.0544

Bergfur, J., B.O.L. Demars, M.I. Stutter, S.J. Langan, and N. Friberg. 2012. The Tarland catchment initiative and its effect on stream water quality and macroinvertebrate indices. J. Environ. Qual. 41:314-321 (this issue). doi: $10.2134 /$ jeq 2010.0537

Borin, M., M. Passoni, M. Thiene, and T. Tempesta. 2010. Multiple functions of buffer strips in farming areas. Eur. J. Agron. 32:103-111.

Costanza, R., R. d'Arge, R. de Groot, S. Farber, M. Grasso, B. Hannon, K. Limburg, S. Naeem, R.V. O’Neill, J. Paruelo, R.G. Raskin, P. Sutton, and M. van der Belt. 1997. The value of the world's ecosystem services and natural capital. Nature 387:253-260. doi:10.1038/387253a0

Dorioz, J.M., D. Wang, J. Poulenhard, and D. Trevisan. 2006. The effect of grass buffer strips on phosphorus dynamics: A critical review and synthesis as a basis for application in agricultural landscapes in France. Agric. Ecosyst. Environ. 117:4-21. doi:10.1016/j.agee.2006.03.029

Dybkjær, J.B., A. Baattrup-Pedersen, B. Kronvang, and H. Thodsen. 2012. Diversity and distribution of riparian plant communities in relation to stream size and eutrophication. J. Environ. Qual. 41:348-354 (this issue). doi:10.2134/jeq2010.0422

Gumiere, S.J., Y. Le Bissonnais, D. Raclot, and B. Cheviron. 2011. Vegetated filter effects on sedimentological connectivity of agricultural catchments in erosion modelling: A review. Earth Surf. Processes Landforms 36:319. doi:10.1002/esp.2042

Heinen, M., I.G.A.M. Noij, H.I.M. Heesmans, J.W. van Groenigen, P. Groenendijk, and J.T.N.M. Thissen. 2012. A novel method to determine buffer strip effectiveness on deep soils. J. Environ. Qual. 41:334-347 (this issue). doi:10.2134/jeq2010.0452

Kirkkala, T., A-M. Ventelä, and M. Tarvainen. 2012. Long-term field-scale experiment on using lime filters in an agricultural catchment. J. Environ. Qual. 41:410-419 (this issue). doi:10.2134/jeq2010.0429

Koo, B., and P. O'Connell. 2006. An integrated modelling and multi-criteria analysis approach to managing nitrate diffuse pollution: 1 . Framework and methodology. Sci. Total Environ. 359:1-16. doi:10.1016/j. scitotenv.2005.05.042

Kronvang, B., I. Wiborg, G. Heckrath, and A. Baattrup-Pedersen. 2010. Multifunctional buffer strips for nature, environment and leisure. (In Danish.) Jord og Viden 155:12-15.

Kronvang, B., H.E. Andersen, P.J. Nordemann, G. Heckrath, G. Rubæk, and C. Kjærgaard. 2011. Effect of $10 \mathrm{~m}$ buffer strips on phosphorus losses. Note to the Danish Environmental Ministry. Aarhus Univ., Aarhus, Denmark.

Kronvang, B., J. Audet, A. Baattrup-Pedersen, H.S. Jensen, and S.E. Larsen. 2012. Phosphorus load to surface water from bank erosion in a Danish lowland river basin. J. Environ. Qual. 41:304-313 (this issue). doi: $10.2134 /$ jeq2010.0434
Liu, X., X. Zhang, and M. Zhang. 2008. Major factors influencing the efficacy of vegetated buffers on sediment trapping: A review and analysis. J. Environ. Qual. 37:1667-1674. doi:10.2134/jeq2007.0437

MacLeod, C.J.A., and R.C. Ferrier. 2011. Temperate grasslands in catchment systems: The role of scale, connectivity and thresholds in the provision and regulation of water quality and quantity. In: G. Lemaire, editor, Grassland productivity and ecosystem services. CABI, Oxford, UK. p. 229-238.

Mander, U., V. Kuusemets, and Y. Hayakawa. 2005. Purification processes, ecological functions, planning and design of riparian zones in agricultural watersheds. Ecol. Eng. 24:421-432. doi:10.1016/j.ecoleng.2005.01.015

Matthews, A. 2011. Post-2013 EU Common agricultural policy, trade and development: A review of legislative proposals. Issue Paper 39. International Centre for Trade and Sustainable Development. Geneva. http:// ictsd.org/downloads/2011/12/post-2013-eu-common-agricultural-policy-trade-and-development.pdf (accessed 31 Jan. 2012).

McCracken, D.I., L.J. Cole, W. Harrison, and D. Robertson. 2012. Improving the farmland biodiversity value of riparian buffer strips: Conflicts and compromises. J. Environ. Qual. 41:355-363 (this issue). doi:10.2134/ jeq2010.0532

Noij, I.G.A.M., M. Heinen, H.I.M. Heesmans, J.T.N.M. Thissen, and P. Groenendijk. 2012. Effectiveness of unfertilized buffer strips for reducing nitrogen loads from agricultural lowlands to surface waters. J. Environ. Qual. 41:322-333 (this issue). doi:10.2134/jeq2010.0545

Roberts, W.M., M.I. Stutter, and P.M. Haygarth. 2012. Phosphorus retention and remobilization in vegetated buffer strips: A review. J. Environ. Qual. 41:389-399 (this issue). doi:10.2134/jeq2010.0543

Schultz, R.C., P.H. Wray, J.P. Colleti, T.M. Isenhart, C.A. Rodrigues, and A. Kuhl. 1997. Stewards of our streams: Buffer strip design, establishment and maintenance. USDA Forest Service, Iowa State Univ., and Leopold Institute for Sustainable Agriculture, Ames, IA.

Stockan, J.A., S.J. Langan, and M.R. Young. 2012. Investigating riparian margins for vegetation patterns and plant-environment relationships in northeast Scotland. J. Environ. Qual. 41:364-372 (this issue). doi: $10.2134 /$ jeq 2010.0518

Stutter, M.I., and S. Richards. 2012. Relationships between soil physicochemical, microbiological properties, and nutrient release in buffer soils compared to field soils. J. Environ. Qual. 41:400-409 (this issue). doi:10.2134/jeq2010.0456

Stutter, M.I., S.J. Langan, and D.G. Lumsdon. 2009. Vegetated buffer strips can lead to increased release of phosphorus to waters: A biogeochemical assessment of the mechanisms. Environ. Sci. Technol. 43:1858-1863. doi:10.1021/es8030193

Uusi-Kämppä, J., E. Turtola, A. Närvänen, L. Jauhiainen, and R. Uusitalo. 2012. Phosphorus mitigation during springtime runoff by amendments applied to grassed soil. J. Environ. Qual. 41:420-426 (this issue). doi:10.2134/jeq2010.0441

Vidon, P. 2010. Riparian zone management and environmental quality: A multi-contaminant challenge. Hydrol. Processes 24:1532-1535. doi:10.1002/hyp.7740

Vidon, P., C. Allan, D. Burns, T.P. Duval, N. Gurwick, S. Inamdar, R. Lowrance, J. Okay, D. Scott, and S. Sebestyen. 2010. Hot spots and hot moments in riparian zones: Potential for improved water quality management. J. Am. Water Resour. Assoc. 46:278-298. doi:10.1111/j.1752-1688.2010.00420.x

Weigelhofer, G., J. Fuchsberger, B. Teufl, N. Welti, and T. Hein. 2012. Effects of riparian forest buffers on in-stream nutrient retention in agricultural catchments. J. Environ. Qual. 41:373-379 (this issue). doi:10.2134/ jeq2010.0436 